\title{
Recenzja książki Jana Kantego Pytla, Chodze za Toba, Chryste. Medytacje dla wszystkich na każdy dzień roku, Poznań 2019, ss. 686
}

Książka ks. prof. zw. dra Jana Kantego Pytla zatytułowana Chodze za Toba, Chryste jest zbiorem komentarzy na uroczystości i święta całego roku, a szczególnie na okresy liturgiczne.

Tytuł książki pochodzi ze znanego wiersza Kazimiery Iłłakowiczówny. Tekstom towarzyszą ilustracje z cyklu „Boży Rok” krakowskiego malarza i ilustratora przełomu XIX i XX wieku Piotra Stachiewicza. Rozważania przeznaczone są jak pisze Autor we Wstępie - dla czcicieli Jezusa, którzy „chcą z Nim rozważać, o Nim myśleć, o Nim czytać”. Tytuły medytacji, często „domyślne”, mają prowokować do zagłębienia się w treść. Autor nie narzuca czytelnikom żadnych gotowych przemyśleń, wniosków czy postanowień, ale zachęca do pochylenia się nad tekstami i osobistej refleksji, prosząc Ducha Świętego, aby prowadził ich do Prawdy.

Książka poświęcona jest na chwałę Pięknej Pani z Fatimy.

\section{Styczeń}

Pierwsza część medytacji (31 tekstów) rozpoczyna się wraz z nowym rokiem kalendarzowym. Otwierają ją rozważania napisane na uroczystość Bożej Rodzicielki Maryi. Tematyka rozważań nawiązuje do kolejnych świąt i uroczystości. Przybliża m.in. historię przywrócenia po latach Uroczystości Objawienia Pańskiego, jednego z najstarszych świąt w Kościele. Przypomina też historię dogmatu o Boskim Macierzyństwie. Opowiada o posłannictwie Jana Chrzciciela, i świadectwie, jakie daje o Chrystusie początkowo sceptycznie nastawiony Natanael. Mówi o cudach rozmnożenia chleba i uzdrowieniu trędowatego, zwracając przy tym uwagę na wiele aspektów tych wydarzeń, których często nie zauważa 
się przy zwykłej lekturze. Komentarze ubogacają też liczne dygresje na temat życia świętych (m.in. Antoniego, Franciszka Salezego, Jana Bosko), aktualnych zdarzeń (m.in. zabójstwo młodej wolontariuszki Heleny Kmieć w Boliwii). Odnajdujemy też teksty z dziedziny poezji religijnej, jak wspomnienie o Franciszku Karpińskim, oświeceniowym twórcy pieśni do dziś śpiewanych w kościele, a nawet motyw babci, o której Biblia wspomina tylko jeden jedyny raz. Jan Kanty Pytel nawiązuje zatem do literatury, filozofii, historii, cywilizacji i kultury. Czerpie z przebogatej skarbnicy swojego umysłu, aby jak najciekawiej, jak najpełniej przekazać głębokie treści teologiczne.

\section{Marzec}

Rozważania marcowe obejmują 19 tekstów na czas Wielkiego Postu. Punktem wyjścia do medytacji stają się m.in. przypowieść o synu marnotrawnym, pytanie Piotra: ile razy mam przebaczać?, cytaty z Księgi Mądrości o prześladowaniu sprawiedliwego, historia cnotliwej Zuzanny, kamienowanie kobiety cudzołożnej. Wątki znane, ale odczytane w nowej perspektywie z licznymi detalami, które pogłębiają rozumienie tekstu. Dzięki temu staje się on bardziej obrazowy, wyrazistszy, nabiera nowej symboliki. Przykładem może być objaśnienie imienia cnotliwej niewiasty z biblijnej przypowieści: Zuzanna to hebr. „szoszana” (lilia); stąd przeniesienie znaczeń. Wyjątkowo pięknie i z żarliwą dydaktyką Autor ukazuje największe przykazanie - przykazanie miłości — tak, aby nikogo nie pozostawić obojętnym. Jak zwykle Autor rozbudowuje komentarze o liczne dygresje, nawiązując też do współczesności, aby niejako przymusić czytelnika do zatrzymania się, skupienia uwagi i refleksji. Dzięki temu nawet często czytane teksty biblijne pojawiają się w innej, nowej odsłonie.

\section{Sobota po Popielcu}

Ten blok rozważań zawiera 28 tekstów od Środy Popielcowej do piątku po II niedzieli Wielkiego Postu. Uwagę zwracają piękne tytuły komentarzy, którymi często są cytaty z Pisma Świętego lub poetyckie sformułowania. Autor jak zwykle stara się przybliżyć, wyjaśnić trudne dla czytelnika zagadnienia, posługując się przykładami znanymi nie tylko z Biblii czy hagiografii, ale i z historii, literatury, sztuki, nauki. Nawiązuje też do wydarzeń obecnych. Chętnie cytuje poezję religijną (np. s. Nulli i K. Iłłakowiczówny), a także pieśni religijne. Przypomina okoliczności powstania hymnu „My chcemy Boga”. Szczegółowo analizuje tekst modlitwy „Ojcze Nasz”. Lubi stosować nieoczekiwane, ciekawe skojarzenia, które stanowią inspirację do dalszych przemyśleń i zmuszają czytelnika, by 
odczytać myśl z innego punktu widzenia. Autor porusza tematy trudne: powołanie Mateusza i dalej: powołanie do świętości, szczeble miłości bliźniego, miłość nieprzyjaciół, nawoływanie do miłości bliźniego i miłosierdzia. Opowiada m.in. znaną ze Starego Testamentu historię Żydówki Estery, z Dziejów Apostolskich historię nawrócenia Szawła, a z czasów nam bliższych - Alexisa Carrela. Wykorzystuje zatem wszelkie okazje, aby podzielić się swoją wiedzą, dotrzeć do odbiorcy, zainspirować go i poruszyć, a w konsekwencji doprowadzić do nawrócenia czy pogłębienia wiary. Do szukania Boga.

\section{Wielki Tydzień}

Ten cykl poświęcony jest rozważaniom na czas od Wielkiego Poniedziałku do Wigilii Paschalnej (sześć tekstów). Rozpoczyna się od medytacji nad proroctwem Izajasza o Słudze Jahwe, które zawiera zapowiedź i opis przyszłego Mesjasza. Potem powracamy myślą do wydarzeń Wielkiego Tygodnia. Poprzedza je uczta w Betanii, namaszczenie cennym olejkiem. Dlaczego Chrystus, tak zawsze troszczący się o ubogich, tym razem bierze w obronę kobietę krytykowaną za „zmarnowanie" olejku nardowego wartego 300 denarów? W kolejnych rozważaniach Autor wprowadza nas w dramaturgię Triduum Paschalnego. Ostatnia Wieczerza, symbolika umycia nóg uczniom przez Mistrza, wskazanie tego, który zdradzi, wymknięcie się Judasza, ustanowienie Eucharystii, rozmowa z Piotrem. Opis Męki Pańskiej jest czytany w kościele w Niedzielę Palmową zamiast kazania, a więc bez komentarza. W niniejszych medytacjach Autor zapewnia taki komentarz; wyjaśnia, poszerza kontekst zdarzeń, pozwala je lepiej zrozumieć, odczytać na nowo. Dzieli się przy tym nie tylko swoją wiedzą, ale również głęboką wiarą. Stale podkreśla, że są to wydarzenia zbawcze; rozważamy je po to, aby dotarły do naszego serca i je zmienily. A droga do przemiany wiedzie przez Eucharystię.

W rozważaniach na okres Wielkiego Tygodnia Autor zmienia styl narracji: nie ubarwia go licznymi dygresjami, nie stosuje żartu, paradoksu, ironii, lecz całą uwagę kieruje wyłącznie na głębokie przeżycie tekstów Pisma Świętego.

\section{Zmartwychwstanie}

W 43 krótkich rozważaniach, których ramę czasową stanowi okres od Niedzieli Wielkanocnej do piątku po VII Niedzieli Wielkanocnej, Autor przedstawia Zmartwychwstanie Jezusa Chrystusa i wszelkie okoliczności związane z tym niezwykłym wydarzeniem opisane w Ewangelii. Ich kontynuacją są wydarzenia relacjonowane przez Apostołów w Dziejach Apostolskich. Stąd każde z rozważań o Zmartwychwstaniu opiera się na wybranych tekstach Nowego Testamentu. 
Jaki jest cel tych rozważań? Umocnienie we wierze. Jak podkreśla bowiem Autor tekstu - wiara tych, którzy mieli chrystofanie, buduje wiarę przyszłych pokoleń, w tym i naszą.

W swoich komentarzach Autor nie tylko relacjonuje i objaśnia wydarzenia, ale daje też ich pogłębioną analizę. Otacza obrazowym i ciekawym kontekstem, czerpanym z wielkiej skarbnicy wiedzy Autora. Dzięki temu tekst nabiera kolorytu, staje się żywy, łatwiejszy do percepcji. Rozważania napisane są piękną, elegancką polszczyzną i pretendują do formy literackiej. Czyta się je dobrze i łatwo, co przy tak trudnej i doniosłej treści jest ogromnym atutem.

Jan Kanty Pytel, wybitny znawca Nowego Testamentu, nie zarzuca nas trudną i specjalistyczną terminologią, ale wiedzę podaje tak, aby tekst był dla każdego zrozumiały. Nazwy własne otrzymują stosowne wyjaśnienia, greckie terminy są przetłumaczone. „Uczoność” Autora nie stanowi bariery dla czytelnika, a tylko go ubogaca. Nie jest to zatem popis erudycji, lecz prawdziwa KATECHEZA.

\section{Czerwiec, lipiec sierpień, wrzesień}

Medytacje na czerwiec, lipiec, sierpień i wrzesień przeznaczone są na każdy dzień i często nawiązują do przypadających w danym miesiącu świąt religijnych i wydarzeń historycznych. I tak w czerwcu dominują rozważania na temat kultu Najświętszego Serca Pana Jezusa, w sierpniu wspomnienie o powstaniu warszawskim, a we wrześniu o II wojnie światowej. Przeplatane są krótkimi katechezami ogólnymi, które są objaśnieniami niektórych pojęć religijnych, biografiami świętych czy postaci historycznych (np. rotmistrz Witold Pilecki).

W świecie skoncentrowanym na takich wartościach jak pieniądz, władza, uroda i zdrowie, Autor przypomina o ludziach, którzy poświęcili te wszystkie wartości dla Boga i bliźnich. Potrafili zapomnieć o sobie i poświęcić swoje życie dla dobra innych. To oni w ostatecznym rozrachunku odnieśli zwycięstwo. Właśnie ich wspominamy z miłością i wdzięcznością. Oni mogą być wzorem i przykładem. Jak zawsze medytacje wzbogacone są licznym dygresjami, cytatami z literatury, anegdotami.

\section{Październik}

Rozważania na październik to 31 krótkich katechez. Kilka tradycyjnie poświęconych jest modlitwie różańcowej. Inne zgodnie z przypadającym na dany dzień Patronem przypominają postacie znanych świętych m.in. św. Teresę z Lisieux, św. Franciszka i św. Faustynę. Autor wspomina też wielkich Polaków zasłużonych dla Kościoła i Ojczyzny jak: św. Jan Paweł II, arcybiskup Lwowa Józef 
Bilczewski i poeta Wincenty Pol. Na podstawie budujących przykładów Autor snuje refleksje ogólne, o dobroci, poświęceniu, wierności ideałom, bohaterstwie męczenników. Katechezy są bardzo zróżnicowane, jeśli chodzi o tematykę: znajdujemy teksty dotyczące problemów współczesnych, opowieści ze Starego Testamentu, a także o Paruzji Chrystusa i charyzmatach. Autor naucza tak, jakby opowiadał: wyjaśnia terminologię, cytuje wiersze, odwołuje się do wydarzeń z historii i literatury. Na każdy dzień miesiąca przeznaczone jest jedno rozważanie, stąd zmiana epok, tematu pozwala uniknąc monotonii. Te krótkie formy czyta się lekko, dobrze zapamiętuje, dzięki czemu mogą stanowić materiał do medytacji na cały dzień.

\section{Listopad}

Teksty przeznaczone na listopad rozpoczynają się genezą uroczystości Wszystkich Świętych (1 listopada) i Wspomnienia Wszystkich Wiernych Zmarłych (2 listopada). Rozważania na kolejne dni miesiąca są przypomnieniem wielkich postaci Kościoła w Polsce: tych, którzy swoje życie poświęcili dla innych nie tylko przez wypełnianie duchowej posługi, ale i dzięki praktykowaniu dzieł miłosierdzia wobec najuboższych. Czytelnik poznaje zatem znanych społeczników jak ks. Piotr Wawrzyniak, Bogdan Jański (współzałożyciel zmartwychwstańców, czyli Zgromadzenia Zmartwychwstania Pana Naszego Jezusa Chrystusa), o. Rafał Chyliński, M. Elżbieta Czacka z Lasek, św. Jan Kanty, bp Józef Sebastian Pelczar (założyciel sercanek, czyli Zgromadzenia Służebnic Najświętszego Serca Jezusowego), bp Teodor Kubina, ks. abp Romuald Jałbrzykowski, bp Zygmunt Łoziński. W kontekście przypadającego w listopadzie Święta Niepodległości Autor wspomina polskich męczenników, którzy oddali życie za wiarę i ojczyznę, a beatyfikowani zostali przez św. Jana Pawła II: m.in. bł. bp. Władysława Gorala i bł. ks. Stefana Wincentego Frelichowskiego. Serdecznie opowiada o dr Izabeli Wolframównie, lekarce, która heroicznie niosła pomoc mieszkańcom Pruszkowa. Rozważania listopadowe można by zatem nazwać litanią polskich świętych i błogosławionych, duchownych i świeckich pełniących dzieła miłosierdzia w duchu miłości Boga i Ojczyzny.

\section{Grudzień}

Teksty na grudzień przygotowują na Narodziny Pana Jezusa. Autor przypomina, że Adwent ma być czasem przygotowania przede wszystkim duchowego. W tym oczekiwaniu na przyjście Syna Bożego niezwykle ważna jest spowiedź, roraty, wyciszenie. W medytacjach Autor wykorzystuje teksty z Pisma św. i Trady- 
cji. Szczególnie istotne są tu dwa terminy: synkatabaza (nachylenie Boga ku ludziom) i kenoza (wyniszczenie, ogołocenie z chwały). Jezus, przychodząc na świat, we wszystkim stał się podobny do ludzi z wyjątkiem grzechu.

Nauki grudniowe dotyczą też przypadających w tym miesiącu ważnych świąt jak: Uroczystość Niepokalanego Poczęcia Najświętszej Maryi Panny, św. Jana, Apostoła i Ewangelisty, św. Szczepana, Świętych Młodzianków Męczenników.

Na zakończenie Autor zamieszcza bardzo osobistą refleksję na podsumowanie nie tylko roku, ale i całego życia. Jest ona pogodnym dziękczynieniem Bogu za to wszystko, czego było mu dane w nim doświadczyć. A jednocześnie jako kapłan wierny swojemu powołaniu, by zawsze nauczać, przestrzega samego siebie i innych słowami z Listu do Hebrajczyków: ,zachęcajcie się wzajemnie każdego dnia, póki trwa to, co dziś się zwie, aby żaden z was nie uległ zatwardziałości przez oszustwo grzechu" (Hbr 3,13).

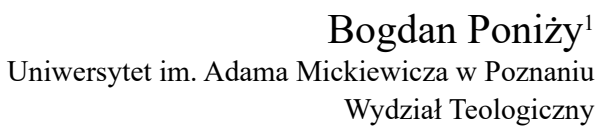

${ }^{1}$ Ksiądz prof. dr hab. Bogdan Poniży — biblista, specjalista w literaturze mądrościowej Starego Testamentu, szczególnie w Księdze Mądrości. Autor wielu monografii i artykułów naukowych; e-mail: ponizy@amu.edu.pl. ORCID: 0000-0002-5186-447X. 